\title{
Structural Protein
}

National Cancer Institute

\section{Source}

National Cancer Institute. Structural Protein. NCI Thesaurus. Code C18073.

Proteins whose major function is to give shape and support to tissues, cells, and subcellular structures. 